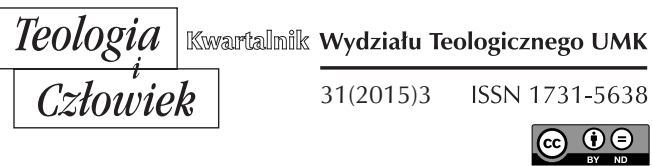

KS. SŁAWOMIR TYKARSKI*

TORUŃ

\title{
ELEMENTY ORGANIZACJI PORADNICTWA - UJĘCIE TEORETYCZNE
}

DOI: http://dx.doi.org/10.12775/TiCz.2015.040

Nie jest przesadą stwierdzenie, że każdy człowiek w jakimś momencie swojego życia potrzebuje pomocy innej osoby, polegającej na udzieleniu wsparcia, pocieszeniu, wysłuchaniu, doradzeniu. Każda jednostka z takiej pomocy korzysta nie zdając sobie sprawy, że jest to forma poradnictwa psychologicznego. Oczywiście najczęściej osoby udzielające pomocy to członkowie rodziny, przyjaciele, znajomi. Jest to zatem struktura pomocy nieprofesjonalnej, udzielonej przez osoby bez specjalistycznego przygotowania, odpowiedniego wykształcenia, lecz cechujące się często doświadczeniem życiowym, mądrością, umiejętnością budowania kontaktu. Niniejszy artykuł odnosi się do drugiego rodzaju poradnictwa, czyli do poradnictwa profesjonalnego. Jest ono zamierzonym działaniem, mającym za cel udzielenie pomocy przez wykwalifiko-

* Ks. Sławomir Tykarski - kapłan diecezji toruńskiej, dr teologii pastoralnej, psychoterapeuta, wykładowca na Wydziale Teologicznym UMK na Kierunku Nauk o Rodzinie. Specjalizuje się w psychoterapii par i małżeństw. Udziela pomocy małżonkom przeżywającym kryzys swojego związku. 
wanego doradcę posiadającego wiedzę, umiejętności i środki niezbędne do pomagania ${ }^{1}$.

We wstępie należy opatrzyć wyjaśnieniem rozumienie sformułowania „organizacja poradnictwa”. Znaczenie tego terminu jest bardzo rozległe. W niniejszej publikacji przez elementy organizacji poradnictwa rozumie się przedmiot, jak też podmiot poradnictwa, metody, czynności, jak również środki poradnicze, cechy doradcy wraz z czynnościami do niego przynależącymi oraz modele pomagania i zjawiska, które występują w procesie poradnianym. Na potrzeby niniejszego artykułu taki sens przybiera rozumienie organizacji poradnictwa.

\section{PORADNICTWO - ZAGADNIENIA WSTĘPNE}

W kontakcie poradniczym można wyróżnić podmiot i przedmiot jego działania. Od razu nasuwa się myśl, iż podmiotem działania jest

1 Więcej na temat pomagania profesjonalnego i nieprofesjonalnego zob. B. Okun, Skuteczna pomoc psychologiczna, Warszawa 2002, s. 8-11; W. Okła, Poradnictwo terapeutyczne, Lublin 2013, s. 62-70. W tym miejscu ważne jest rozróżnienie dwóch terminów: „poradnictwa” i „doradztwa”. Poradnictwo polega na udzieleniu pomocy przed doradcę w taki sposób, aby jednostka jej szukająca wypracowała system samopomocowy i przy udziale oraz wsparciu profesjonalisty stopniowo doszła do rozwiązania problemu. Pomoc rozumiana w takim ujęciu sprowadza się do uruchomienia zasobów osoby zgłaszającej się do poradni w celu wypracowania w niej samodzielnego radzenia sobie z problemami, które do tej pory były dla niej nie do przezwyciężenia. Doradztwo zaś polega na udzieleniu pomocy poprzez danie gotowych rozwiązań, konkretnych porad, instruktaży czy wskazówek. Jest to zaspokojenie konkretnych potrzeb zgłaszającego się bez uwzględnienia jego osobistego rozwoju, uczenia go, jak ma sobie radzić w przyszłości wykorzystując swoje zasoby. Poradnictwo należy również odróżnić od psychoterapii, którą za Aleksandrowiczem można zdefiniować jako „oddziaływanie psychologiczne, mające na celu leczenie - usuwanie zaburzeń, przeżywanych przez jednostkę lub określonych przez otoczenie jako choroba” oraz od interwencji kryzysowej, która według Greenstone’a i Levitona jest „umiejętnym wkroczeniem we właściwym momencie w sytuację kryzysu osoby (lub osób), by opanować stan, który grozi jej (im) destrukcją emocjonalną lub fizyczną”. Natomiast poradnictwo według Sęka jest formą pomocy „oferowanej osobom zdrowym, doświadczającym problemów życiowych, trudności przystosowawczych i kryzysów rozwojowych". J. Aleksandrowicz, Psychoterapia medyczna, Warszawa 1996, s. 15; J. Greenstone, S. Leviton, Interwencja kryzysowa, Gdańsk 2004, s. 13; H. Sęk, Wprowadzenie do psychologii klinicznej, Warszawa 2001, s. 182. 
doradca. Czyżby przedmiotem działania poradniczego byłaby osoba szukająca pomocy? Takie podejście jest nie do przyjęcia ze względu na to, że szukający pomocy nie jest pozbawiony aktywności ani nie występuje jednostronne zmienianie wspomaganego (klienta) poprzez oddziaływanie doradcy. Po pierwsze wspomagany zgłasza się do poradni, przez co uruchamia proces pomocowy. Po drugie przy udzielaniu pomocy nie istnieje relacja jednostronna, lecz jest obecne współdziałanie, a więc zachodzą interakcje wywołujące wzajemne zmiany zarówno w doradcy, jak i u radzącego się. Po trzecie odbiorca porady jest osobą, która może samostanowić o sobie, być aktywna, dokonująca samodzielnych wyborów, być autorem swojego życia, posiadać własny system wartości. W związku z tym w kontakcie poradniczym podmiot działania jest diadą składającą się z osoby doradcy oraz osoby szukającej pomocy z dookreśleniem, że jeden z członów (zgłaszający) znajduje się w sytuacji problemowej, której nie potrafi rozwiązać z powodu braku wiedzy, umiejętności, wsparcia innych osób bądź wystąpienia nieznanej mu dotąd trudnej sytuacji życiowej $^{2}$. W ten sposób dochodzi się do zdefiniowania czym jest poradnictwo i jak je należy rozumieć. Jest to pomoc sytuacyjna o charakterze takiej „interakcji społecznej, w której dwie (lub więcej) osoby oddziałują na siebie za pomocą bezpośredniej komunikacji, modyfikując nawzajem swoje zachowanie"3. Są to uwarunkowania, w których doradca posługuje się zabiegami werbalnymi mającymi charakter terapeutyczny, psychoedukacyjny. Niemniej poradnictwo można rozumieć również jako sytuację w znaczeniu głębokiego przeżycia osób w niej uczestniczących. W takich okolicznościach poradniczych szczególnie zwraca się uwagę na przeżycia wspomaganego, jego odczucia, emocje, nadzieje, obawy ${ }^{4}$.

Przedstawiona koncepcja poradnictwa nawiązuje do podejścia liberalnego, jak też dialogowego opartego na podłożu humanistycznym, wypracowanym przez Carla Rogersa, w którym radzący się, przy udziale doradcy i w klimacie bezpieczeństwa, sam dochodzi do zmian, rozwiąza-

2 Zob. A. Kargulowa, O teorii i praktyce poradnictwa. Podręcznik akademicki, Warszawa 2011, s. 38-39.

3 Tamże, s. 47.

4 Zob. B. Wojtasik, Sytuacja poradnicza - między rytuałem interakcyjnym a prawdziwym spotkaniem, w: Poradoznawstwo - kontynuacja dyskursu, red. A. Kargulowa, Warszawa 2009, s. 200. 
nia problemu przez dialog oraz współpracę. Takie podejście stoi w opozycji do poradnictwa dyrektywnego, gdzie radzący się jest traktowany przed doradcę instrumentalnie stając się przedmiotem (a nie podmiotem) działania poradniczego 5 . Doradca nadzoruje proces pomagania, nie wykorzystuje zasobów radzącego się, przekonuje go do swojego sposobu spostrzegania i myślenia.

Przedmiotem działania poradniczego jest nic innego, jak problem, którego nie potrafi rozwiązać zgłaszający się do poradni. Sytuacja problemowa jest przez niego spostrzegana jako coś trudnego, negatywnego, niechcianego, stresującego. Problem to nic innego jak rodzaj zadania, „którego radzący się nie może rozwiązać przy aktualnie posiadanym poziomie wiedzy, umiejętności i nastawienia"6. Obszary problemowe mogą mieć różną naturę, być związane ze stanem psychofizycznym jednostki, sytuacją rodzinną, zawodową, z pełnieniem różnych ról społecznych oraz wypełnieniem zadań z nimi związanych. Rozwiązanie problemu zależy zarówno od doradcy, jak też od osoby szukającej pomocy, którą mobilizuje się do podjęcia zmiany, m.in. poprzez rzucanie nowego światła na sytuację problemową (zmiana percepcji), przekształcanie jej stosunku do czynników stresogennych.

Powyższe rozważania na temat podmiotu, a także przedmiotu działania poradniczego składają się na tak zwany interakcyjny model poradnictwa. Oprócz tych dwóch podmiotów działania (doradca - radzący się) i przedmiotu (zgłaszany problem), na interakcyjny model składają się także czynności poradnicze, metody, środki działania, wyniki działania?. Obrazuje to poniższy schemat:

${ }^{5}$ Poszerzoną refleksję nad różnicami w poradnictwie liberalnym, dialogowym i dyrektywnym zob. B. Skałbania, Poradnictwo pedagogiczne. Przegląd wybranych zagadnień, Kraków 2009, s. 51-53.

${ }^{6}$ E. Kozdrowicz, cyt. za K. Smól, Poradnictwo telefoniczne na przykładzie fundacji Itaka, w: Refleksje o poradnictwie debiutujących doradców, red. D. Zielińska-Pękał, Zielona Góra 2009, s. 66. Zob. też M. Szumigraj, O problemie w poradnictwie, w: Poradoznawstwo kontynuacja dyskursu, s. 179.

7 Zob. E. Kozdrowicz, Poradnictwo w teorii i praktyce, w: Pedagogika społeczna. Człowiek w zmieniającym się świecie, red. T. Pilch, I. Lepaczyk, Warszawa 2003, s. 324. 


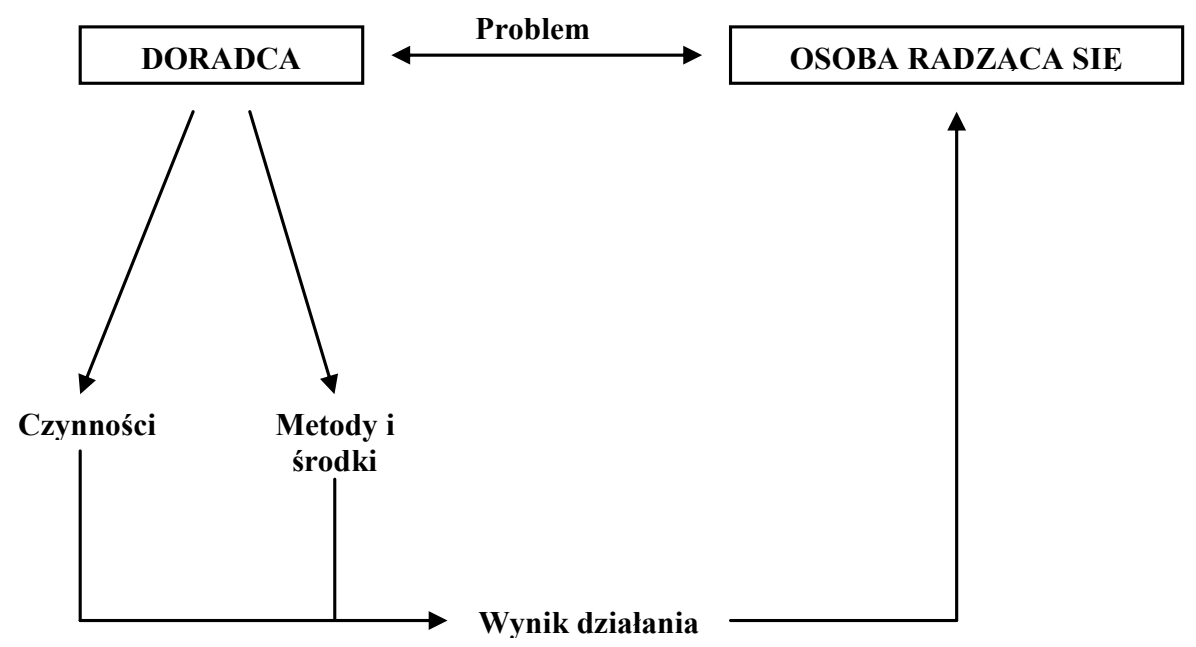

Źródło: E. Kozdrowicz, Poradnictwo w teorii i praktyce, s. 325.

Do podstawowych czynności poradniczych można zaliczyć:

- badania wstępne (wywiad, pozyskiwanie informacji, wstępne zrozumienie problemu, potrzeb, trudności osoby szukającej pomocy),

- diagnoza (na przykład psychologiczna, pedagogiczna),

- prognoza i program pomocy ${ }^{8}$.

Odnośnie metod oraz środków wykorzystywanych w procesie poradniczym podstawową jest metoda werbalna używana w bezpośrednim kontakcie pomagającego z szukającym pomocy9. To poprzez rozmowę buduje się kontakt między dwoma podmiotami, a więc kształtuje zaufanie radzącego się do doradcy. Natomiast środki stosowane w procesie poradnianym są tożsame z tymi, które wykorzystują psycholodzy czy pedagodzy. Są to narzędzia w postaci kwestionariuszy, ankiet czy skal. Za środki również można uznać wiedzę doradcy, doświadczenie, empatię, umiejętność

8 Zob. Tamże, s. 329.

9 Zob. A. Kargulowa, dz. cyt., s. 45. Metoda werbalna jest stosowna w kontakcie bezpośrednim. Jeśli porada nie ma takiego charakteru metodą może być porada udzielona $\mathrm{w}$ listach, na łamach prasy, w książkach, audycjach radiowych bądź programach telewizyjnych (tzw. poradnictwo zapośredniczone). Zob. E. Kozdrowicz, dz. cyt., s. 330; D. Zielińska-Pękał, Poradnictwo a świat mediów, czyli o poradnictwie zapośredniczonym, w: Poradoznawstwo - kontynuacja dyskursu, s. 285-307. 
prognozowania wyników stosowanych strategii pomocowych. Używane metody i środki mają wpływ na wyniki działania w postaci rozwiązania problemu, zmotywowania radzącego się do dokonania zmiany swojej sytuacji życiowej, osobistego rozwoju, weryfikacji, a w konsekwencji na modyfikację zachowania, wyuczenie nowych sposobów radzenia sobie. Wyniki działania mogą również dotyczyć samego doradcy w postaci analizy sposobu udzielanej pomocy, adekwatności i skuteczności narzędzi, które zastosował w procesie poradnianym.

Podsumowując powyższe treści, poradnictwo jest relacją międzyosobową opartą na podmiotowości dwóch stron (doradcy i wspomaganego). Dochodzi między nimi do interakcji, w której odgrywają znaczenie ich cechy osobowe, motywacja, wykorzystywane metody i narzędzia w celu uzyskania korzystnych zmian w zachowaniu u zgłaszającego się do poradni - rozwiązania problemu i udzieleniu mu wsparcia oraz pomocy w sytuacji dla niego trudnej bądź kryzysowej ${ }^{10}$.

\section{CHARAKTERYSTYKA CECH I CZYNNOŚCI DORADCY11}

Podstawowym zadaniem doradcy jest udzielenie pomocy w szerokim znaczeniu tego słowa. Nie zawsze oznacza to rozwiązanie problemu, z którym zgłasza się jednostka. Pomocą może być już jej wysłuchanie, udzielenie psychiczno-emocjonalnego wsparcia, okazanie empatii. Dlatego niezmiernie ważny jest kontakt, jaki buduje doradca ze wspomaganym. Dzieje się to przez okazywanie zainteresowania jego problemem i tym, co ma do przekazania, empatyczne wczuwanie się w jego sytuację życiową, dawanie potwierdzenia uważnego słuchania, czujność na komunikaty niewerbalne, zachowania, reakcje, jakie wysyła wspomagany ${ }^{12}$.

10 Zob. B. Skałbania, dz. cyt., s. 23.

${ }^{11} \mathrm{~W}$ podejściu do procesu pomagania i roli doradcy mogą występować odmienne koncepcje ze względu na różne orientacje psychologiczne. Wśród nich wyróżnia się przede wszystkim koncepcję psychoanalityczną, behawioralno-poznawczą, humanistyczno-egzystencjalną. W niniejszym artykule charakterystyka cech doradcy bazuje na podejściu humanistyczno-egzystencjalnym. O głównych założeniach i podstawowych różnicach w wymienionych koncepcjach zob. B. Skałbania, dz. cyt., s. 31-36.

${ }^{12}$ Wśród pomocnych zachowań werbalnych $\mathrm{w}$ relacji pomagania można wy- 
Według Rogersa doradca winien odznaczać się trzema podstawowymi cechami, które stanowią warunek skuteczności w udzielaniu pomocy, a są nimi: empatia, ciepło i autentyczność ${ }^{13}$. Empatia to zdolność wczuwania się w świat osoby wspomaganej w taki sposób, jakby był to świat doradcy. To wniknięcie w sytuację innej osoby w celu jej zrozumienia $\mathrm{z}$ zastrzeżeniem, że nie chodzi o zwykłe zrozumienie jej położenia poprzez intelektualne zgłębienie warunków egzystencjalnych, lecz o wrażliwość na doznania i przeżycia wspomaganego. Zadanie to nie należy do łatwych, bowiem trudno osiągnąć stan całkowitej empatii. Pomocą w tym zadaniu może posłużyć odzwierciedlenie treści, polegające na wyrażeniu („odbiciu”) znaczenia usłyszanych treści oraz przedstawienie uczuć, polegające na weryfikacji zawartych w przekazie emocji, które są powiązane $\mathrm{z}$ wypowiedzianymi treściami. W odzwierciadleniu uczuć pomocne jest stosowanie opisów stanów emocjonalnych jednostki poprzez używanie określeń przymiotnikowych. Jeśli osoba mówi: „Czuję niepokój”, to w odpowiedzi doradca może użyć określeń: „Jest pani napięta, zmartwiona, zestresowana, dogłębnie przejęta”. Każde z nich ma inny sens, jednakże odcień znaczeniowy może być sprawą kluczową dla osoby wspomaganej. Przez odzwierciedlenie treści doradca komunikuje, że oprócz odebranych treści przyjął również ładunek emocjonalny, który jest z nimi związany.

różnić: minimalne reakcje werbalne tupu: „mhm”, „aha”, parafrazowanie, sondowanie, odzwierciedlenie, klaryfikację, interpretowanie, konfrontowanie, informowanie, podsumowywanie. Natomiast do pomocnych zachowań niewerbalnych można zaliczyć: dostosowanie tonu głosu doradcy do tonu głosu wspomaganego, utrzymywanie kontaktu wzrokowego, potakiwanie głową, zachowanie żywej mimiki, umiarkowana gestykulacja, uśmiechanie się we właściwych momentach, umiarkowane tempo mowy. Więcej na ten temat zob. B. Okun, dz. cyt., s. 31-32, 82-84.

13 Zob. S. Murgatroyd, Poradnictwo i pomoc, Poznań 2000, s. 28. Szeroką refleksję nad znaczeniem empatii, ciepła i autentyczności znajdziesz w: D. Mearns, B. Throne, Terapia skoncentrowana na osobie, Kraków 2010, s. 67-150; M. Cooper, Efektywność psychoterapii i poradnictwa psychologicznego. Wyniki badań i praktyka kliniczna, Warszawa 2010, s. 148-154. Niektórzy autorzy wyróżniają jeszcze inne cechy doradcy warunkujące skuteczne pomaganie. Wśród nich można wymienić: konkretność, samoświadomość, wiedza i umiejętności (kompetencje), etyczne zachowanie. Więcej na ten temat zob. B. Okun, dz. cyt., s. 38-41; S. Murgatroyd, dz. cyt., s. 42-51; W. Okła, dz. cyt., s. 86-90; J. Milner, P. O’Bryne, Poradnictwo krótkoterminowe: narracje i rozwiązania, Poznań 2007, s. 49-50. 
Drugą cechą doradcy w udzielaniu pomocy jest ciepło nazywane przez Rogersa „bezwarunkowym życzliwym spojrzeniem”. Sformułowanie to rozumiał w znaczeniu bezwarunkowej akceptacji człowieka, szanowaniu go za to, kim jest i jaki jest, jego indywidualności i niepowtarzalności oraz prawa do samostanowienia. Ważne jest bowiem dla wspomaganego, by czuł, że doradca go akceptuje bez względu na to, co zrobił, co przeżywa. Zadaniem doradcy jest zatem stworzenie atmosfery, w której jednostka poczuje się bezpiecznie.

Trzecią cechą warunkującą skuteczne poradnictwo jest według Rogersa autentyczność. Polega ona na zbieżności mowy doradcy z tym, co wyraża język jego ciała. To zgodność reakcji z wewnętrznym doświadczeniem, kongruencja pomiędzy tym, co myśli i odczuwa; a tym, co wypowiada do klienta i jak się wobec niego zachowuje. Sam Rogers ujmował tę cechę następująco:

Uważam, że najważniejszym elementem w relacji terapeutycznej jest prawdziwość terapeuty. Wiele wskazuje na to, że jesteśmy szczególnie skuteczni w chwilach całkowitej naturalności i spontaniczności. (...) Dlatego właśnie niezmiernie zróżnicowani terapeuci osiągają dobre rezultaty na bardzo różne sposoby. W przypadku jednego terapeuty sprawdza się postawa osoby niecierpliwej, zasadniczej, bezceremonialnej - przyjmując ją, jest bowiem najbardziej sobą. Inny terapeuta jest znacznie bardziej serdeczny i łagodny, ponieważ taki właśnie jest. Wieloletnie doświadczenia ugruntowały mój pogląd, że skutecznym terapeutą jest ta osoba, która w danej chwili potrafi otwarcie być sobą i sięgać do najgłębszych pokładów swojego jestestwa. Być może nic nie jest tak równie istotne ${ }^{14}$.

Przejawem autentyczności doradcy będzie chociażby jego śmiech, gdy wspomagany powie coś zabawnego, przyznanie się do dezorientacji, kiedy się pojawia, wyrażenie słowami sympatii, gdy się ją odczuwa. Innymi słowy to, co jest najbardziej lecznicze i wspólne dla wszystkich podejść w psychoterapii, to stworzona relacja między doradcą a wspomaganym. Okazuje się bowiem, że związek terapeutyczny jest ważniejszy od korektywnego doświadczenia emocjonalnego, możliwości poznania siebie czy wypracowania nowych sposób zachowania, zaś jakość relacji, poziom empatii doradcy i jego osobiste cechy są ściśle związane z rezultatami pro-

${ }^{14}$ Cyt. za D. Mearns, B. Throne, dz. cyt., s. 117. 
cesu pomagania (bądź terapii) ${ }^{15}$. Zatem to, co „uzdrawia” to nie metody, obrane strategie czy wykorzystane narzędzia, które stosuje doradca, lecz jakość relacji, którą nawiązał z osobą szukającą pomocy.

\section{MODELE RELACJI POMAGANIA}

Jak już wcześniej zostało zasygnalizowane, w podejściu do procesu pomagania mogą występować odmienne koncepcje ze względu na różne orientacje psychologiczne. Prezentowany model pomagania bazuje na koncentracji na osobie i został wypracowany w latach trzydziestych oraz czterdziestych XIX wieku przez Carla Rogersa, który był przeciwny sztywności podejścia psychoanalitycznego, które w tamtym czasie zdominowało poradnictwo psychologiczne. Główne zasady pomagania skoncentrowanego na kliencie zakładają racjonalność osoby, jej dobroć, zdolność do wzięcia odpowiedzialności za swoje życie, dokonywania wyborów, autonomię jednostki, skłonność do współpracy, podejmowanie działań mających celowy charakter na rzecz zaspokojenia swoich potrzeb, zdolność uczenia się nowych zachowań z jednoczesnym wygaszaniem postępowania do tej pory stosowanego, rozwiązywanie problemów „tu i teraz” (koncentracja na wyborach osoby dostępnych w teraźniejszości), mimo że niektóre $\mathrm{z}$ nich mogą mieć swoje źródło w przeszłości ${ }^{16}$. Jest to teoria bazująca na poglądzie, że funkcjonujemy zgodnie $z$ własnym obrazem swojej osoby. Taki typ podejścia ma charakter fenomenologiczny, ponieważ ważniejsze jest osobiste spostrzeganie klienta samego i swojej sytuacji od spostrzegania doradcy lub otoczenia. Źródłem problemów klienta jest zachodząca rozbieżność między obrazem samego siebie a życiowym doświadczeniem. Sprzeczność ta jest zagrażająca dla ja jednostki, która stosuje mechanizmy obronne w postaci zaprzeczenia albo zniekształcenia doświadczeń, co prowadzi do destabilizacji jej życia, a dalej cierpienia. Rolą doradcy jest okazanie klientowi bezwarunkowej akceptacji, ponadto stworzenie

15 Więcej na ten temat zob. J. Cz. Czabała, Czynniki leczace w psychoterapii, Warszawa 2006; M. Cooper, dz. cyt., s. 172; G. R. Collins, Poradnictwo chrześcijańskie, Warszawa 2005, s. 30.

16 Zob. B. Okun, dz. cyt., s. 15-17. 
empatycznej relacji, co spowoduje jego otwartość na własne przeżycia i osiągnięcie spójności obrazu jego „ja” z zachowaniem. Osiągnięte zmiany mogą być efektem zrozumienia przez klienta własnych uczuć, percepcji, zachowań. Doradca, poprzez budowanie relacji, pomaga wspomaganemu w rozumieniu samego siebie ${ }^{17}$.

Bazując na koncepcji Okun, w modelu pomagania można wyróżnić dwie fazy. Pierwsza $z$ nich polega na budowaniu relacji poprzez zdobycie zaufania, które jest podstawą skuteczności każdej strategii pomagania. Faza budowania relacji składa się z następujących etapów: „inicjacja (otwarcie), rozpoznanie i klaryfikacja zgłoszonego problemu (lub problemów), uzgodnienie struktury relacji (kontrakt), intensywna eksploracja problemu (problemów), określenie możliwych celów relacji pomagania"18. Zbudowanie relacji jest wyjściem dla drugiej fazy pomagania, czyli fazy zastosowania strategii. W swej strukturze obejmuje ona: „obopólną akceptację określonych celów relacji, planowanie strategii, zastosowanie strategii, ocenę strategii, zakończenie, kontakty postterapeutyczne"19.

Różni autorzy wymieniają odmienne etapy pomagania. Dla przykładu Brammer wyróżnia osiem stadiów pomagania: „Wstęp - przygotowanie i nawiązanie relacji. Klasyfikacja - ustalenie problemu i powodów szukania pomocy przez wspomaganego. Strukturowanie - sformułowanie kontraktu i struktury (istota, granice i cele przyszłej relacji pomagania). Relacja - budowanie relacji pomagania. Eksploracja - eksplorowanie problemów, formułowanie celów, planowanie strategii, zbieranie faktów, wyrażanie głębszych uczuć, uczenie nowych umiejętności. Konsolidacja eksplorowanie alternatyw, przepracowanie uczuć, praktykowanie nowych umiejętności. Planowanie - stosowanie strategii rozwiązywania konfliktów, redukowanie przykrych uczuć, podejmowanie samodzielnych działań przez wspomaganego z równoczesnym włączeniem nowych umiejętności czy zachowań. Zakończenie - ewaluacja wyników i zakończenie relacji”20. Natomiast Egan w swojej koncepcji pomagania wyróżnia trzy etapy:

17 Zob. B. Okun, dz. cyt., s. 124; D. Mearns, B. Throne, dz. cyt., s. 7-18.

18 B. Okun, dz. cyt., s. 19, 91-119.

19 Tamże, s. 19, 219-252.

${ }^{20}$ L. M. Brammer, Kontakty służące pomaganiu. Procesy i umiejętności, Warszawa 1984, s. $68-84$. 
„I Etap - Zrozumienie problemu, czyli jasne określenie kluczowych kwestii wymagających zmiany:

A. Pomoc w wypowiedzeniu się, nazwaniu i personalizacji problemu.

B. Pomoc w zrozumieniu problemu i siebie.

C. Pomoc w uchwyceniu tego, co istotne oraz tego, co ma się zmienić.

Efektem końcowym tego etapu jest to, co nowego klient dowiedział się o sobie, uświadomienie, że to jego problem (personalizacja), jaki jest ciężar gatunkowy problemu (ciężar gatunkowy = dystres x częstotliwość z kontrolowalność), ale też chęć zmiany.

II Etap - Poszukiwanie dróg wyjścia, czyli wybieranie optymalnego scenariusza zmiany:

A. Pomoc w podejmowaniu decyzji co zmienić.

B. Pomoc w ustaleniu celów, do jakich chce zmierzać.

C. Pomoc w podejmowaniu ostatecznej decyzji.

Efektem tego etapu jest jasna decyzja, co chce zmienić i jak chce to osiągnąć. Cel ten powinien być: realistyczny, konkretny, jasno sformułowany, zgodny z systemem wartości, efektywny, określony w czasie.

III Etap - Strategie działania i wprowadzenie ich w życie:

A. Pomoc w ustalaniu właściwych strategii działania.

B. Pomoc w wyborze najlepszej strategii.

C. Pomoc we wprowadzeniu strategii w życie.

Efektem tego etapu jest podjęcie przez klienta konkretnych czynności na rzecz rozwiązania problemu, a ze strony doradcy wzmocnienie i czuwanie nad wprowadzeniem zmian w życie"21.

W przytoczonych modelach podstawą powodzenia procesu pomagania jest wypracowanie relacji opartej na zaufaniu między doradcą a klientem ${ }^{22}$. Kreowanie relacji ma miejsce już podczas pierwszego spotkania. Tworzą się wówczas warunki, w których wspomagany może

${ }^{21}$ W. Okła, dz. cyt., s. 119-120. Zob. też G. Egan, Kompetentne pomaganie. Model pomocy oparty na procesie rozwiązywania problemów, Poznań 2002, s. 49-72. Przykłady innych modeli pomagania zob.: H. Sęk, dz. cyt., s. 232; J. Cz. Czabała, Czynniki leczące w psychoterapii, Warszawa 1997, s. 173.

${ }^{22} \mathrm{Na}$ temat specyficznych elementów i cech relacji zob. W. Okła, dz. cyt., s. $101-104$. 
przedstawić swoje problemy czy trudności. Dzięki relacji zaczyna lepiej rozumieć, jakie znaczenie i konsekwencje mają one dla jego obecnego życia. Dzięki udanej relacji klient wraz z doradcą mogą wspólnie ustalić cele, do realizacji których ma dążyć proces pomagania. Znając je, doradca może dobrać i zastosować odpowiednie strategie, jak również wraz z klientem dokonać ewentualnych ich korekt, modyfikacji. Niemniej rozwinięcie ciepłej relacji jest fundamentem każdej stosowanej strategii przez pomagającego. Pomocą na tym etapie służą umiejętności komunikacyjne doradcy oraz jego niepowtarzalna osobowość i osobiste cechy. Pomagający korzysta ze strategii po to, by klient lepiej sam siebie zrozumiał, dokonał analizy swojego zachowania w celu powiększenia poziomu samoakceptacji, odpowiedzialności za własne wybory. Ponadto stosowanie strategii ma doprowadzić do poprawienia funkcjonowania klienta $w$ trzech sferach: afektywnej (odczuwania), behawioralnej (zachowania, działania), poznawczej (myślenia). Zakończenie procesu pomagania zachodzi po osiągnięciu rezultatów uzgodnionych wcześniej przez doradcę i wspomaganego, jak też po upewnieniu się, że klient ma wystarczająco sił, aby osiągnięte $\mathrm{w}$ trakcie relacji pomagania zmiany trwały po zakończeniu procesu, to znaczy, aby potrafił on w przyszłych sytuacjach życiowych stosować to, czego się nauczył w relacji z doradcą.

\section{ZJAWISKA ZACHODZĄCE W PROCESIE PORADNIANYM}

W procesie pomagania nie można zapomnieć o zjawiskach, które mają wpływ na proces pomagania. Można wyróżnić cztery kategorie: zjawiska pomocne i oczekiwane, pomocne i nieoczekiwane, utrudniające i oczekiwane, utrudniające i nieoczekiwane ${ }^{23}$.

Nawiązując do pierwszego zjawiska elementami pomocnymi i oczekiwanymi są wyżej wymienione fazy: kształtowania relacji i zastosowania strategii ze szczególnym naciskiem na sposób otwarcia (inicjacja) oraz budowania zaufania. Pomocnym zjawiskiem jest również odreagowanie emocjonalne, dzięki któremu klient może „wyrzucić” z siebie kumulowane emocje, zmniejszając powstałe napięcie. Kolejnym czynnikiem

23 Tamże, s. 116. 
pomocnym jest wgląd, czyli uczynienie świadomym tego, co do tej pory było dla wspomaganego nieuświadomione. To poznanie mechanizmów działania oraz ich źródeł. Skutkiem wglądu jest realistyczna ocena samego siebie i swoich możliwości, zwiększenie zaufania do własnej osoby, odpowiedzialności za własne życie, dokonywane wybory, jak też zmiana dotychczasowych sposobów radzenia sobie. Pomocnym czynnikiem jest również wypracowanie nowych zachowań, a ponadto sprawdzanie ich funkcjonowania w życiu (faza strategii).

Zjawiska pomocne i nieoczekiwane to pojawienie się niespodziewanych okoliczności, które pomagają w realizacji procesu poradnianego. Mogą nimi być wystrój gabinetu, wiek czy wygląd doradcy przypominający osobę, którą klient darzy sympatią, znalezienie przez klienta pracy, którą stracił, co miało wpływ na jego samopoczucie i relacje rodzinne.

Przykładem zjawisk utrudniających i oczekiwanych jest opór klienta przed zmianą jego funkcjonowania. Mimo że osoba szuka pomocy w rozwiązaniu problemu, to niekiedy może wykazywać niechęć do podjęcia wysiłku zmiany swojego życia, do uczynienia wglądu, czyli poszerzenia swojej świadomości. Opór jest brakiem współpracy klienta z doradcą, przejawiającym się $\mathrm{w}$ braku szczerości w wypowiedziach, niemówieniu o wszystkich kluczowych informacjach, znajdowaniu tematów zastępczych, pomijaniu sfery emocjonalnej, intelektualizowaniu, zdawkowych odpowiedziach, nadmiernym milczeniu, spóźnianiu się na umówione spotkania bądź ich częstym odwoływaniu. Źródłem oporu może być lęk klienta przed niepochlebną oceną ze strony doradcy, poczucie wstydu bądź winy. Dlatego zadaniem doradcy jest akceptacja pojawienia się oporu, który informuje go o braku pełnego zaufania klienta. W związku z tym, aby pokonać opór musi skoncentrować się przede wszystkim na wzmocnieniu zaufania. Następnie winien ukazać wspomaganemu, że opór utrudnia ich współpracę, po czym razem podjąć refleksję, do czego klientowi służy jego stosowanie. Kolejnym działaniem jest przepracowanie, czyli wyuczenie się nowego zachowania $\mathrm{w}$ miejsce stosowanego uprzednio oporu ${ }^{24}$.

${ }^{24}$ Więcej na temat mechanizmu oporu zob. J. A. Kottler, Opór w psychoterapii. Jak pracować z trudnym klientem?, Gdańsk 2003; A. Leźnicka-Łoś, Podstawy terapii psychoanalitycznej. Teoria i praktyka, Gdańsk 2012, s. 121-141. 
Ostatnim rodzajem zjawisk mających wpływ na proces pomagania są zjawiska utrudniające i nieoczekiwane. Są to okoliczności, których nie można było przewidzieć, a które negatywnie wpływają na proces pomagania. Zaliczyć do nich można pragnienie klienta do częstszych i nieformalnych spotkań z doradcą, chęć utrzymywania relacji towarzyskich, wręczanie prezentów, nagłe nieszczęście bądź tragedia w życiu klienta (śmierć kogoś bliskiego, wypadek, choroba).

Niniejszy artykuł miał na celu omówienie w ujęciu teoretycznym podstawowych elementów organizacji poradnictwa, na które składają się: przedmiot i podmiot poradnictwa, metody, czynności, środki poradnicze, cechy doradcy i czynności do niego należące oraz model pomagania wraz ze zjawiskami, które występują w procesie poradnianym. Ze względu na różne orientacje psychologiczne, które warunkują odmienne podejście do procesu pomagania i roli doradcy, wybrano i skupiono się tylko na podejściu egzystencjalnym $\mathrm{z}$ koncentracją na osobie, wypracowaną przez Carla Rogersa. Autor rozumie, że przedstawione treści są tylko zarysem problematyki, którą można by ująć w perspektywie innych płaszczyzn, odmiennego doboru zagadnień oraz ich pogłębienia.

Streszczenie. Każdy człowiek w jakimś momencie swojego życia potrzebuje pomocy drugiej osoby, polegającej na udzieleniu wsparcia, pocieszeniu, wysłuchaniu, doradzeniu. W dużej mierze odbywa się to w sposób nieprofesjonalny poprzez członków rodziny, przyjaciól, znajomych, ale także w kontekście grup formalnych, jak i nieformalnych. Można jednak zauważyć, że w Polsce coraz częściej ludzie korzystają z profesjonalnej pomocy w gabinetach psychologów, psychoterapeutów czy pedagogów. Cieszy ten fakt, bowiem obala się niesłuszne przekonanie społeczne i niesprawiedliwą stygmatyzację, że osoba szukająca pomocy u specjalisty jest słaba, nieporadna życiowo lub chora psychicznie. W związku z tym powstaje coraz więcej profesjonalnych poradni. Stąd też powód powstania niniejszej publikacji, która omawia podstawowe elementy poradnictwa w założeniach teoretycznych, na które składają się: przedmiot i podmiot poradnictwa, metody, czynności, środki poradnicze, cechy doradcy, ale też czynności do niego należące oraz modele pomagania wraz ze zjawiskami, które występują w procesie poradnianym.

Słowa kluczowe: organizacja poradnictwa; poradnictwo; doradca; klient; pomoc; porada; wsparcie; relacja.

Abstract. Elements of counseling organization - theoretical perspective. Every man at some point of his life needs the help from another person, consisting in granting support which is: consolation, listening, and giving advice. To a large degree it happens 
unprofessionally because of family members and friends, but also in the context of the formal and informal groups. However it can be noticed that in Poland more often people use professional help and support from the psychologists, psychotherapists and educators. It is a positive thing because in fact it refutes a wrongful conviction and unjust social stigma that the person seeking help from a professional is poor, clumsy practically or mentally ill. Therefore, more and more professional clinics are being opened. Hence the reason for the smaller publication that covers the basic elements of guidance in theoretical assumptions, which include: the subject and the object of guidance, methods, activities and resources counseling, features advisers and activities, which belong to them, and models to help with the phenomena that occur in the process of counseling settings.

Keywords: organization of counseling; advice; advisor; customer; help; advice; support; relationship. 
